\title{
PERENCANAAN BISNIS SISTEM INFORMASI PERCETAKAN ONLINE BERBASIS APLIKASI WEB
}

\author{
Laser Narindro ${ }^{1}$, Hendra MayaTopani ${ }^{2}$ \\ Universitas Muhammadiyah Tangerang / Fakultas Teknik, \\ Program Studi Informatika \\ Jl. Perintis Kemerdekaan 1/33 Cikokol Kota Tangerang TLP. 55793251, 55772949, 55793802, 55736926 \\ e-mail: laser_narindro87@yahoo.com,dra_maya_topani@yahoo.com
}

\begin{abstract}
Abstrak
Persaingan bisnis dewasa ini tak hanya bertumpu pada kualitas produk, melainkan lebih pada kualitas layanan, yang lebih mendorong pelanggan untuk kembali membeli produk atau menggunakan solusi yang ditawarkan. Namun, tidak berarti produk yang dipasarkan boleh yang tidak bermutu, terutama jika produk yang ditawarkan memiliki pesaing yang kurang lebih sama. Lain halnya untuk produk-produk yang secara esensial bersifat unik, bermutu tinggi dan memiliki diferensiasi yang kuat, sehingga pelanggan akan memiliki value yang jelas, meskipun ada produkproduk yang sejenis. Untuk membuka wirausaha perlu dipertimbangkan secara matang mengenai perencanaan usahanya yang akan dijalankan. Perencanaan yang matang akan menentukan hasil sesuai dengan apa yang diharapkan, sehingga usahanya dapat berlangsung terus-menerus. Penelitian ini bertujuan untuk membuat suatu model perencanaan bisnis percetakan online berbasis aplikasi web dan mengetahui model perencanaan bisnis yang layak untuk direalisasikan. Perencanaan bisnis percetakan online berbasis aplikasi web akan menjelaskan perencanaan bisnis yang mengoptimalkan fungsi teknologi informasi sebagai pendukung kegiatan transaksi dan operasional usaha tersebut.
\end{abstract}

Kata kunci: Perencanaan bisnis, teknologi informasi, percetakan online berbasis aplikasi web.

\begin{abstract}
The evolution of technology of information right now can affects human lifestyle so each individuals forced to follow the evolution so they are not left behind from the technology of information. Technology and information system this time already become a requirement and information resource for the users. This time, every fans of music, especially the fans of angklung instrumental, even for a beginner or a professionals hoping that's someday there will be a development for an application of angklung instrumental based on android who can complete the needed of angklung instrumental users as a tools to education and entertainment who can play anywhere and anytime through a hardware called smartphone with android's platform. This angklung application production is using an application called java eclipse, so when using this angklung application the users can get the details information, interactive with good and can conserve this traditional angklung instrumental.
\end{abstract}

Keywords: angklung application, smartphone, android's platform, java eclipse

\section{Pendahuluan \\ Persaingan bisnis dewasa ini tak hanya bertumpu pada kualitas produk,}

melainkan lebih pada kualitas layanan, yang lebih mendorong pelanggan untuk kembali 
membeli produk atau menggunakan solusi yang ditawarkan. Namun, tidak berarti produk yang dipasarkan boleh yang tidak bermutu, terutama jika produk yang ditawarkan memiliki pesaing yang kurang lebih sama. Lain halnya untuk produk-produk yang secara esensial bersifat unik, bermutu tinggi dan memiliki diferensiasi yang kuat, sehingga pelanggan akan memiliki value yang jelas, meskipun ada produk-produk yang sejenis.

Dengan dukungan teknologi informasi yang berkembang pesat pada saat ini akan membuat orang bergantung pada teknologi. Teknologi diciptakan melalui inovasi dan ide-ide yang bermunculan dari kehidupan sehari-hari. Sedangkan untuk menjalankan proses bisnis ini membutuhkan sebuah sistem informasi yang terintegrasi dan online serta real time untuk menjalankan proses bisnis ini. Karena dari web tersebut akan menjadi media perantara antara pemilik usaha dengan para pelanggannya yang ingin memakai jasa usahanya. Menurut survei yang telah dilakukan oleh SMECDA (salah satu lembaga yang terkait oleh Departemen Koperasi dan UKM), tingkat penggunaan teknologi informasi pada UMKM untuk mendukung kegiatan bisnis mereka dalam berbagai sektor dapat dilihat pada. Gambargambar berikut [3].

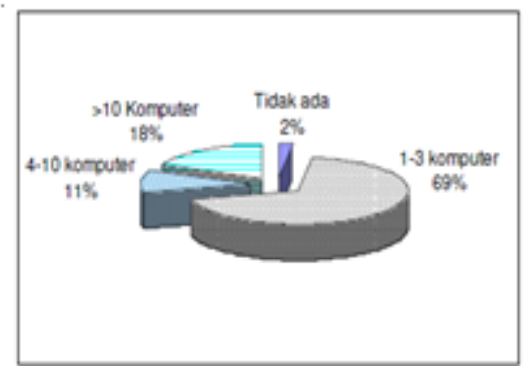

Gambar 1.1 Jumlah Komputer Yang Dimiliki Oleh UMKM

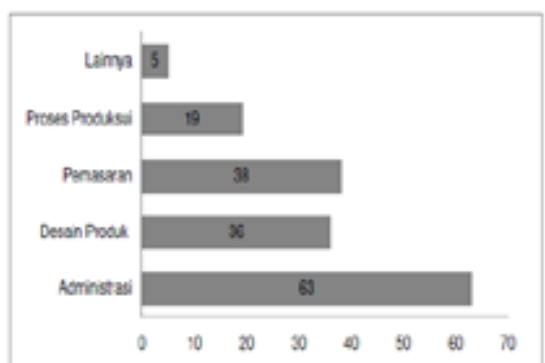

Gambar 1.2 Bidang Penggunaan TI Pada UMKM

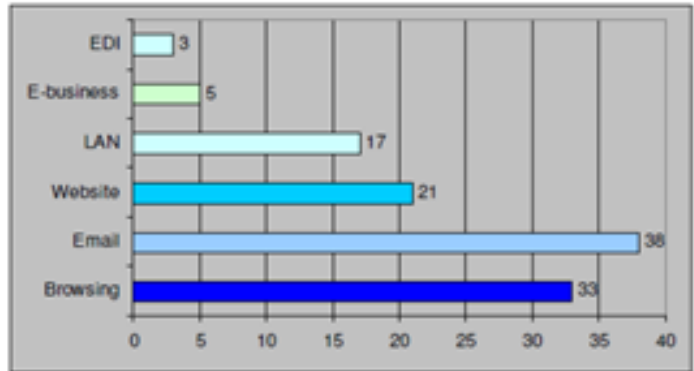

Gambar 1.3 Penggunaan Teknologi Internet Pada UMKM|

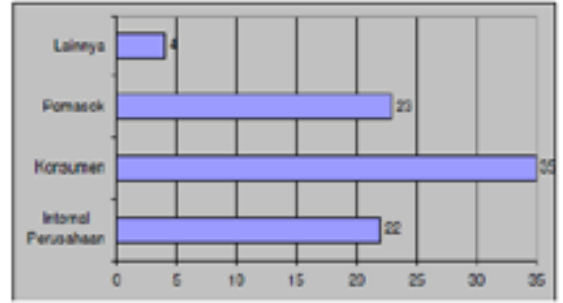

Gambar 1.4 Fungsi Komunikasi Via Email

Teknologi diciptakan melalui inovasi dan ide-ide yang bermunculan dari kehidupan sehari-hari. Sedangkan untuk menjalankan proses bisnis ini membutuhkan sebuah sistem informasi yang terintegrasi dan online

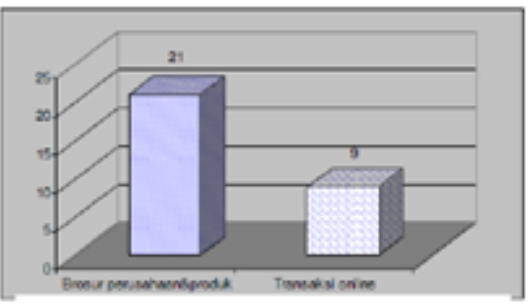

Gambar 1.5 Fungsi Website

serta real time untuk menjalankan proses bisnis ini. Karena dari web tersebut akan menjadi media perantara antara pemilik usaha dengan para pelanggannya yang ingin memakai jasa usahanya. Penggunaan fungsi 
teknologi informasi pada UMKM di berbagai bidang di Indonesia membawa kita untuk mengajukan pertanyaan-pertanyaan berikut penelitian tersebut:

1) Siapakah segmentasi pelanggan dari bisnis percetakan secara online berbabsis aplikasi web yang dituju ?

2) Bagaimana kelayakan untuk perencanaan keuangan dari bisnis percetakan online berbasis aplikasi web ini ?

3) Fungsi IT dan IS apa sajakah yang dapat diterapkan pada bisnis percetakan online berbasis aplikasi web ini ?
Dari penjelasan yang telah paparkan di atas, maka peluang usaha percetakan dengan menggunakan media online berbasis aplikasi web sebagai sarana promosi dan penjualan cukup menjanjikan dimana pangsa pasar untuk bisnis ini masih terbuka menawarkan kemudahan bagi pelanggan yang ingin menggunakan jasa pelayanan percetakan tersebut yaitu dapat melakukan transaksi pemesanan melalui media portal web dan selain itu web tersebut juga sebagai media promosi produk yang ditawarkan perusahaan.

\section{METODE}

Tabel 3.1 Kerangka Berfikir

a. Kerangka Berfikir

\begin{tabular}{|c|c|}
\hline Ide bisnis & $\begin{array}{l}\text { Berdasarkan pengamatan yang telah dilakoukan sebelumnya maka timbulah sebuah } \\
\text { gagasan tentang konsep awal bignis yang akan dijalani }\end{array}$ \\
\hline $\begin{array}{l}\text { Pengumpulan data } \\
\text { dan informosi }\end{array}$ & $\begin{array}{l}\text { Pencarian data dan informasi yang terkait dengan ide bisnis yang akan } \\
\text { dijalani }\end{array}$ \\
\hline $\begin{array}{l}\text { Analisis pasar, supplier } \\
\text { dan kompecitor }\end{array}$ & $\begin{array}{l}\text { Pada tahap ini akan dilakukan survei terhadap pasar untuk produk yang akan } \\
\text { dihasilkan dan kompetitor sejenis yang telah ada }\end{array}$ \\
\hline $\begin{array}{l}\text { Perencanaan proses } \\
\text { produksi }\end{array}$ & adap alur proses pelaksanaan produksi yang \\
\hline $\begin{array}{l}\text { Analisis perencanaan } \\
\text { keuangan }\end{array}$ & $\begin{array}{l}\text { Menghitung perencanaan keuangan secara keseluruhan mulai dari } \\
\text { kebutuhan produksi hingga pendapatan dari produk yang akan dihasilkan }\end{array}$ \\
\hline Analisis resiko & $\begin{array}{l}\text { Menganalisis resiko-resiko yang akan terjadi termasuk kebijakan yang akan atau } \\
\text { telah ditetapkan oleh pemerintah dan kenungkinan resiko yang terjadi lainnya }\end{array}$ \\
\hline $\begin{array}{l}\text { Analisis perencanasn } \\
\text { SDM }\end{array}$ & $\begin{array}{l}\text { Membuat struktural tim dengan kualitas SDM yang gesuai dengan kebutuhan tim } \\
\text { tersebut dan pemberian wewenang pekerjan pada getiap tim tersebut }\end{array}$ \\
\hline $\begin{array}{l}\text { Analisis perencanaan } \\
\text { pemasaran }\end{array}$ & $\begin{array}{l}\text { Menganalisis proses dan bentuk pemasaran produk yang akan ditawarkan kepada } \\
\text { pasar berdasarkan survei pasar yang telah dilakukan terlebih dahulu }\end{array}$ \\
\hline Perencanaan bisnis & $\begin{array}{l}\text { Pembuatan perencanaan bisnis berdasarkan analisis dan survei yang telah } \\
\text { dilakukan sebelumnya }\end{array}$ \\
\hline
\end{tabular}




\section{b. Analisis Proses Bisnis Dengan Menggunakan Model Bisnis Canvas}

Dari kerangka berfikir di atas, maka proses bisnis dapat dianalisis dengan model bisnis yang telah ditentukan. Untuk analisis proses bisnis dalam pembuatan perencanaan bisnis kali ini menggunakan analisis model bisnis canvas. Dengan model bisnis ini dan semakin banyaknya peluang usaha membuat beberapa orang merubah pemikirannya untuk menjalani ide bisnis yang telah dipikirkannya.
Dari analisis proses bisnis tersebut yang berisikan sembilan elemen bisnis, dapat dilihat seberapa besar peluang kesiapan perencanaan bisnis yang akan dijalani ini, sebagai berikut :

Gambar 3.1 Model Bisnis Canvas Percetakan Melalui Media Online

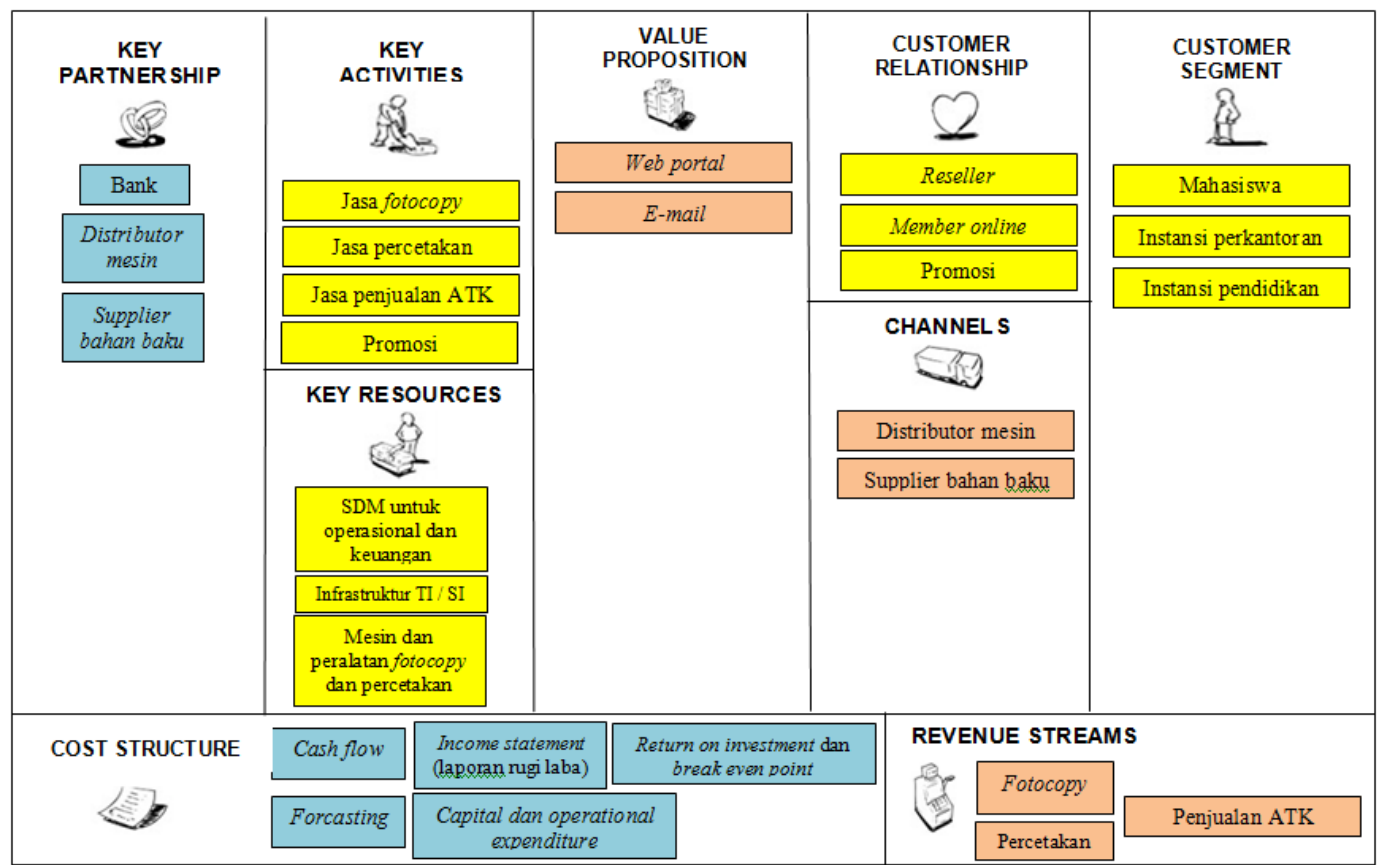

\section{HASIL PEMBAHASAN ANALISIS}

\subsection{Executive Summary}

Percetakan (printing) merupakan teknologi atau seni yang memproduksi salinan dari sebuah gambar (image) dengan sangat cepat, seperti kata-kata atau gambargambar (images) di atas kertas, kain dan permukaan-permukaan lainnya. Setiap harinya, milyaran bahan cetak diproduksi, termasuk buku, kalender, buletin, majalah, surat kabar, poster, undangan pernikahan, perangko, kertas dinding, dan bahan kain. Hal ini karena hasil percetakan dapat dengan cepat mengomunikasikan pemikiran dan informasi ke jutaan orang. Dalam hal ini, pelanggan yang ingin menggunakan jasa pelayanan percetakan pada perusahaan, tidak harus mengunjungi tempat produkdsi dan penjualan jasa percetakan ini tetapi dapat melakukan transaksi tersebut melalui media portal web tersebut. Ketersediaan web bukan hanya sebagai media promosi produk perusahaan yang ditawarkan oleh perusahaan saja tetapi juga membantu pelanggan untuk melakukan pemesanan jasa produk percetakan. Dengan demikian, dari sisi perusahaan juga dapat mengontrol jumlah transaksi yang dihasilkan melalui media online berbasis aplikasi web tersebut 
dan mengestimasikan pemasukan untuk perusahaan.

Segmentasi pelanggan untuk rencana pengembangan bisnis percetakan online berbasis aplikasi web ini yaitu mahasiswa yang berkuliah pada Universitas Negeri Jakarta (UNJ) yang mengambil Jurusan Seni Rupa dan Desain yang masih kuliah pada tahun-tahun awal perkuliahan. Sedangkan untuk return of investment (ROI) rata-rata sebesar $57,04 \%$ dan break event point (BEP) rata-rata adalah sebesar Rp730.162.000 atau 38,34 \% dari pendapatan. Untuk net present value (NPV) yang dihasilkan menunjukkan angka yang positif yaitu sebesar $\mathrm{Rp}$ 2.163.794.000 sehingga layak untuk dilaksanakan sedangkan internal rate of return (IRR) yang dihasilkan sebesar 24,33 \% yang berarti diatas tingkat suku bunga pinjaman bank yang diasumsikan sebesar $12 \%$, sehingga layak untuk dilaksanakan. Sedangkan untuk profitability index yang diperoleh lebih dari 1 yaitu sebesar 1,6767 sehingga layak untuk dilaksanakan. Payback periode yang diperoleh dari perencanaan bisnis adalah selama 5 tahun 11 bulan.

\subsection{Segmentasi Pelanggan}

Adapun hasil dari suvei segmentasi pelanggan pada perencanaan bisnis percetakan dan fotocopy online ini ialah mahasiswa yang berkuliah pada Universitas Negeri Jakarta (UNJ) yang mengambil Jurusan Seni Rupa dan Desain.

Adapun target value proposition yang ditawarkan oleh konsep usaha ini yaitu kemudahan dalam melakukan transaksi pemesanan jasa layanan fotocopy dan percetakan melalui media online berupa aplikasi web e-commerce ataupun aplikasi email.

\subsection{Analisis Porter Five Forces}

Dalam hal ini, analisis kompetitor akan dijelaskan menggunakan metode analisis five forces, sebagai berikut:

\section{Ancaman pendatang baru}

Konsep usaha percetakan dan fotocopy online berbasis web ini merupakan usaha baru. Dimana proses produksinya masih sama dengan usaha percetakan dan fotocopy pada umumnya tetapi yang membedakan ialah proses pemesanan serta pengolahan data percetakan tersebut saja yang berbeda yaitu dilakukan secara online.

2. Tingkat rivalitas dengan pesaing yang ada

Adapun kompetitor sejenis yang telah menerapkan fungsi $\mathrm{TI}$ yang telah ada dan sudah dikenal oleh masyarakat luas, yaitu :

Tabel 3.1 Kompetitor Pada Bidang Usaha Sejenis

\begin{tabular}{|c|c|c|}
\hline Pesaing & Keunggulan & Kelemahan \\
\hline $\begin{array}{l}\text { Zenta copy \& printing } \\
\text { http://zentacopyprint.blogspot } \\
\text {.com/ }\end{array}$ & 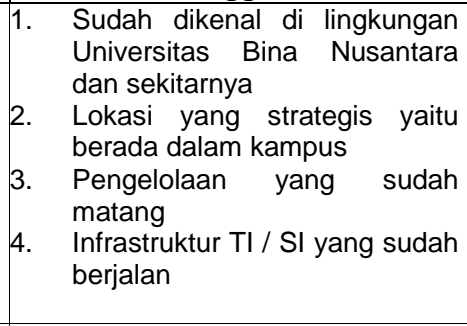 & $\begin{array}{l}\text { 1. Hanya terkenal dalam lingkungan } \\
\text { Universitas Bina Nusantara dan } \\
\text { sekitarnya saja } \\
\text { 2. Segmentasi pelanggan sebagian } \\
\text { besar hanya kalangan akademisi } \\
\text { saja } \\
\text { 3. Hanya terdapat web berupa blog } \\
\text { saja dan tidak menerima transaksi } \\
\text { pemesanan melalui media aplikasi } \\
\text { web blog tersebut }\end{array}$ \\
\hline $\begin{array}{l}\text { Primascan printing } \\
\text { http://www.primascan- } \\
\text { digital.com/ }\end{array}$ & $\begin{array}{ll}\text { 1. } & \text { Dikenal luas oleh masyarakat } \\
\text { 2. } & \begin{array}{l}\text { Produk dan pelayanan lebih } \\
\text { bervariasi }\end{array} \\
\text { 3. } & \begin{array}{l}\text { Permodalan yang sudah } \\
\text { matang }\end{array} \\
\text { 4. } & \begin{array}{l}\text { Infrastruktur } \mathrm{TI} \text { dan } \mathrm{SI} \text { yang } \\
\text { sudah berjalan }\end{array}\end{array}$ & $\begin{array}{l}\text { 1. Segmentasi pelanggan hanya di } \\
\text { daerah Semarang dan sekitarnya } \\
\text { saja } \\
\text { 2. Hanya melakukan transaksi dalam } \\
\text { jumlah besar karena bukan tipikal } \\
\text { jenis usaha retail dalam skala } \\
\text { besar } \\
\text { 3. Tidak mempunyai jasa layanan } \\
\text { fotocopy dan pekerjaan percetakan } \\
\text { lainnya hanya terfokus oleh digital } \\
\text { printing saja }\end{array}$ \\
\hline
\end{tabular}




\begin{tabular}{|c|c|c|}
\hline $\begin{array}{l}\text { Snapy Printing } \\
\text { http://www.snapy.co.id }\end{array}$ & 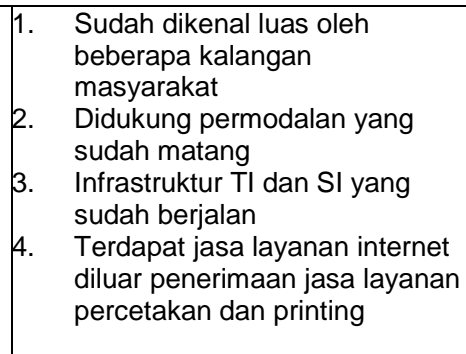 & $\begin{array}{l}\text { 1. Segmentasi pelanggan hanya untuk } \\
\text { kalangan menengah terutama hanya } \\
\text { di daerah Jakarta dan sekitarnya } \\
\text { 2. Tidak mempunyai jasa layanan } \\
\text { fotocopy dan jasa percetakan lainnya } \\
\text { 3. Dikarenakan tipikal usaha ini ialah } \\
\text { tipikal franchise sehingga terdapat } \\
\text { komitmen dalam kontrak kerja } \\
\text { kepada perusahaan pemilik } \\
\text { franchise }\end{array}$ \\
\hline
\end{tabular}

\section{Kekuatan daya tawar pembeli}

Dalam persaingan harga antar tempat usaha percetakan dan fotocopy satu dan lainnya tidak mempengaruhi daya tawar pembeli dikarenakan perbedaan harga tidak terlalu signifikan sehingga pembeli dapat memilih tempat percetakan dan fotocopy sesuai yang diinginkannya dan tingkat kepuasaan atas hasil pengerjaan (produk) yang dihasilkannya serta kualitas pelayanan yang diberikan kepada pelanggan.

\section{Tekanan dari produk pengganti}

Jika dulu pelanggan ingin melakukan transaksi percetakan spanduk masih menggunakan sistem manual yaitu sablon, sekarang telah hadir mesin digital printing dimana hasil yang dikeluarkan lebih baik dan perbedaan harga yang tidak terlalu jauh membuat konsumen beralih memakai jasa mesin digital printing ini serta waktu pengerjaan yang lebih cepat dibandingkan dari metode sablon.

\section{Kekuatan daya tawar pemasok}

Daya tawar-menawar pemasok ini relatif merata dikarenakan selisih harga antara pemasok satu dengan lainnya relatif sedikit sehingga untuk menjalankan usaha ini tidak lagi dikhawatirkan oleh pemilihan pemasok dan jumlah pemasok bahan baku percetakan dan fotocopy sehingga sirkulasi bahan baku yang digunakanpun sudah dengan mudah didapatkan terlebih sistem pembayaran yang ditawarkan pun (cash dan tempo) sangat membantu pengelolaan usaha ini untuk tetap menjalankan usahanya.

Jadi kesimpulan yang dapat diambil dari analisis porter five forces adalah bahwa peluang percetakan dengan menggunakan media online berbasis aplikasi web sebagai sarana promosi dan penjualan ini masih dapat berkembang dikarenakan keberadaan kompetitor dengan jenis usaha sejenis dan produk pengganti pun masih jarang ditemui serta dengan terdapatnya infrastruktur TI dan SI pada usaha ini tidak mempengaruhi harga jual yang siginifikan sehingga daya beli pelanggan pun masih terjangkau.

\subsection{Strategi Pemasaran}

Untuk memperkenalkan produk yang dihasilkan oleh perusahaan kepada pasar maka diperlukan suatu strategi yang digunakan juga harus efektif dan efesien. Tujuan dari pemasaran juga untuk meningkatkan daya beli dari konsumen. Adapun strategi pemasaran yang akan dilakukan, yaitu :

1. Membuat sistem aplikasi berbasis web (e-commerce) agar para pelanggan terutama yang lokasinya tidak dapat terjangkau sehingga mereka tetap dapat melakukan order di perusahaan ini serta sebagai media promosi online $(e-$ commerce).

2. Membuat thread di beberapa forum jual beli, hal ini dapat dilakukan saat ini karena forum komunitas sudah semakin digunakan dimasyarakat dan banyak masyarakat mencari atau menawarkan jasa lewat dunia maya ini.

3. Social media marketing dimana selain memasang iklan di beberapa situs periklanan atau forum komunitas, social media marketing juga dapat memperkenalkan perusahan serta jasa produk yang ditawarkan dikarenakan pengguna aktif social media cukup tinggi sehingga memudahkan perusahaan untuk mempromosikan jasanya. 


\subsection{Perencanaan Operasional}

Dalam dunia usaha atau bisnis, peran sistem konvensional sudah mulai berubah menjadi sistem yang didukung oleh teknologi informasi sendiri. Untuk mendukung proses bisnis suatu perusahaan, maka hampir semua tingkatan dalam bisnis, memakai dukungan teknologi informasi untuk membantu operasional usaha tersebut. Adapun kebutuhan infrastruktur TI dan SI yang digunakan dalam perencanaan bisnis ini, sebagai berikut :

a. Perangkat Keras (hardware)

Kebutuhan perangkat keras (hardware) untuk mengaplikasikan teknologi informasi dalam usaha percetakan dan foto copy online ini adalah sebagai berikut :

1. 1 unit PC (personal computer) yang digunakan sebagai server.

2. 2 unit PC untuk operasional.

3. 2 unit printer deskjet untuk perangkat pencetak dokumen.

4. 2 unit mesin fotocopy untuk perangkat pencetak dokumen.

5. 1 unit mesin banner untuk perangkat pencetak spanduk dan lain-lain.

6. 1 Unit mesin digital printing untuk perangkat pencetak poster dan lain-lain.

7. Kabel LAN (Local Area Networking) sebagai perangkat penghubung antar komputer untuk bertransaksi data

8. 1 unit Hub Switch sebagai perangkat koneksi jaringan komputer untuk area lokal.

9. 1 unit router sebagai perangkat penyebar jaringan internet untuk lokal ( $W i F i)$.

10. Jaringan internet FO berkapasitas 1 Mbps dengan perbandingan $1: 1$

\section{b. Perangkat Lunak (software)}

Adapun tampilan perangkat lunak yang akan digunakan dalam usaha ini berupa aplikasi portal web yang digunakan untuk melakukan transaksi pemesanan jasa percetakan melalui situs www.moesgraph.net sebagai berikut :

\section{Gambar 3.2 Tampilan Index Pada Portal Web}

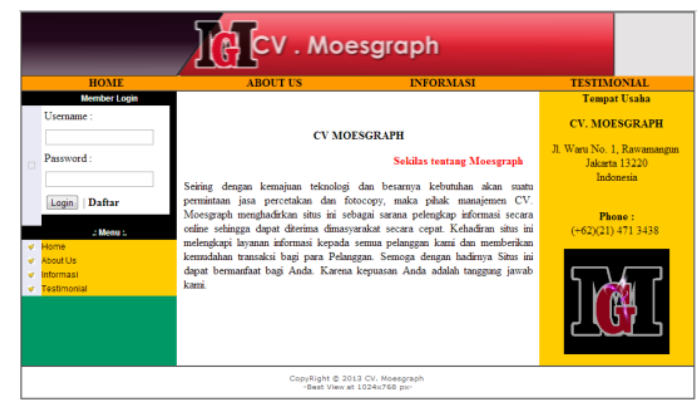

\subsection{Analisis Keuangan}

Inti atau hal yang terpenting dari sebuah perencanaan bisnis ialah perhitungan keuangan karena menentukan layak atau tidaknya perencaaan ini untuk direalisasi. Pada perencanaan pengembangan usaha fotocopy dan percetakan ini menggunakan beberapa asumsi.

1. Pendapatan fotocopy dan percetakan pada tahun pertama adalah sebesar Rp. 65.000 .000 per bulan dan meningkat sebesar $15 \%$ per tahun pada tahuntahun selanjutnya.

2. Beban pemasaran, operasional dan beban lannya adalah masing-masing adalah sebesar $1 \%, 10 \%$ dan $1 \%$ dari pendapatan.

3. Suku bunga pinjaman bank adalah sebesar $12 \%$ per tahun

4. Kenaikan beban penjualan, administrasi dan umum serta beban lainnya masingmasing adalah sebesar $1 \%, 5 \%$ dan 2 $\%$ per tahun.

5. Suku bunga deposito adalah sebesar 6 $\%$ per tahun.

Kebutuhan dana untuk pengembangan sebesar Rp. 2.410.800.000 dipenuhi dari pinjaman Bank dan pendanaan sendiri (self financing). Pada umumnya apabila pihak Bank telah menyetujui proposal perencanaan bisnis yang telah diajukan, pihak Bank hanya akan memberi sebesar $70 \%$ atau sebesar Rp. 1687.560 .000 dari total kebutuhan dana yang diajukan dan dan sisanya sebesar $30 \%$ atau sebesar Rp. 723.240.000 dari pendanaan sendiri.

\section{Break Event Point (BEP)}

Perhitungan BEP rencana pengembangan usaha percetakan online 
berbasis web dapat dilihat pada Tabel 4.11 yaitu sebesar Rp. 730.162.000 atau 38,34\% dari Pendapatan (dalam prosentase) dan payback periode yang dihasilkan yaitu selama 5 tahun 11 bulan.

\section{Return On Investment (ROI)}

Return On Investment (ROI) pada perusahaan dikalkulasi sesuai dengan jumlah investasi yang telah dikeluarkan atau capex yang dibagi oleh keuntungan bersih (net profit). Adapun perhitungan $\mathrm{ROI}$ untuk perencanaan usaha percetakan online berbasis web adalah sebesar $57,04 \%$ seperti terlihat pada Tabel 4.12.

\section{KESIMPULAN \& SARAN}

\subsection{Kesimpulan}

Berdasarkan penjelasan yang sudah dibahas pada bab-bab sebelumnya, maka dapat diambil kesimpulan untuk menjawab indentifikasi masalah pada Bab I yaitu sebagai berikut :

1. Segmentasi pelanggan untuk rencana pengembangan bisnis percetakan online berbasis aplikasi web ini yaitu mahasiswa yang berkuliah pada Universitas Negeri Jakarta (UNJ) yang mengambil Jurusan Seni Rupa dan Desain yang masih kuliah pada tahun-tahun awal perkuliahan.

2. Analisis kelayakan perencanaan keuangan dari pengembangan bisnis percetakan dengan menggunakan media online berbasis aplikasi web sebagai sarana promosi dan penjualan ini adalah menggunakan parameter sebagai berikut

a. Return of Investment (ROI) rata-rata sebesar $57,04 \%$.

b. Break Event Point (BEP) rata-rata adalah sebesar Rp730.162.000 atau $38,34 \%$ dari pendapatan.

c. Net Present Value (NPV) yang dihasilkan menunjukkan angka yang positif yaitu sebesar Rp2.163.794.000 sehingga layak untuk dilaksanakan.

d. Internal Rate of Return (IRR) yang dihasilkan sebesar 24,33\% yang berarti diatas tingkat diskonto yang diasumsikan sebesar $12 \%$, sehingga layak untuk dilaksanakan.

\section{Proyeksi Keuangan (Forecasting)}

Forecasting atau melakukan proyeksi terhadap posisi keuangan dalam neraca (balance sheet), laporan laba dan rugi (income statement) serta arus kas (cash flow). Perusahaan sehingga dapat diketahui kekayaan, hutang, pendapatan, biaya dan laba yang akan dicapai oleh perusahaan dalam jangka waktu tertentu dapat dilihat pada Tabel 4.12, dengan hasil perhitungan sebagai berikut :

a. Net Present Value (NPV) yang dihasilkan menunjukkan angka yang positif yaitu sebesar Rp 2.163.794.000.

b. Internal Rate of Return (IRR) yang dihasilkan sebesar $24,33 \%$

c. Profitability Index sebesar 1,6767.

e. Profitability Index yang diperoleh lebih dari 1 yaitu sebesar 1,6767 sehingga layak untuk dilaksanakan.

f. Untuk payback periode yang diperoleh adalah selama 5 tahun 11 bulan.

3. Peluang usaha dari percetakan dengan menggunakan media online berbasis Aplikasi web sebagai sarana promosi dan penjualan masih cukup besar karena masih sedikit perusahaan sejenis yang menerapkan fungsi tersebut. Disisi lain, pelanggan mendapatkan kemudahan dan kenyamanan dalam memperoleh pelayanan perusahaan karena dapat mengoptimalkan peran $\mathrm{TI}$ dan $\mathrm{SI}$ yang berkembangan saat ini.

\subsection{Saran}

Berdasarkan penjelasan yang sudah dilakukan sebelumnya, saran-saran yang dapat diberikan penulis untuk pengembangan lebih lanjut terhadap rencana pengembangan bisnis percetakan online berbasis aplikasi web yaitu :

1. Melakukan pengembangan terhadap segmentasi pelanggan yang lebih luas seperti segmentasi pelanggan pada scope perkantoran dan beberapa instansi pendidikan lainnya baik formal maupun informal. Disamping itu, seiring dengan perkembangan infrastruktur TI dan SI yang telah dan akan terjadi, diharapkan dapat meningkatkan cakupan segmentasi 
pelanggan yang tidak hanya terdapat dalam wilayah lokal saja tetapi ke beberapa tempat yang yang sulit terjangkau karena terpisah oleh jarak dan waktu.

2. Karena akan terjadinya pengembangan dari sisi infrastruktur $\mathrm{TI}$ dan SI serta peralatan produksi maka diperlukan pengembangan perencanaan keuangan dalam waktu ke depannya sehingga proses produksi dan pendapatan dapat terus ditingkatkan kembali.
3. Diperlukan pengembangan yang berkelanjutan terhadap infrastruktur $\mathrm{TI}$ dan SI agar dapat menjangkau pelanggan di daerah-daerah lain dan disisi lain perusahaan juga dapat melakukan pengontrolan yang lebih baik dalam setiap transaksi pemesanan, keuangan dan kinerja manajemen. Untuk mendukung kegiatan-kegiatan tersebut, maka harus dilakukan perencanaan keuangan yang tepat. 


\section{REFERENSI}

[1] Direktorat Perbankan Syariah, Bank Indonesia. Model Bisnis Perbankan Syariah. 2012.

[2] Smecda. 2010. "Perkembangan Data Usaha Mikro, Kecil Dan Menegah (Umkm) Dan Usaha Besar (Ub) Pada Tahun 2006 - 2010".

[3] Smecda. 2010. "Strategi Peningkatan Kemampuan Adopsi Teknologi Informasi Untuk Meningkatkan Daya Saing Ukm".

[4] Basu, Amit \& Muylle, Steve. 2008. "How To Plan E-Business Initiatives In Established Companies".

[5] Ekaputra, Setephanus. 2010. "Analisa Strategi Pemasaran Asuransi Jiwa Unit Link Pt. Axa Life Indonesia".

[6] Hamid. 2011. "Pengembangan "Technopreneurship" Di Perguruan Tinggi

[7] Dan Implikasi Kebijakannya".

[8] Hurriyati, Ratih. 2012. "Penerapan Model Strategi Pemasaran Usaha Kecil Berbasis Web 2.0 Sebagai Upaya Dalam Meningkatkan Daya Saing Industri Kecil".

[9] Husnan, Suad.,. Suwarono, 1994, Studi Kelayakan Proyek, Edisi Ketiga, Upp Amp Ykp Yogyakarta

[10] Ibrahim, Yacob., 2003, Studi Kelayakan Bisnis, Cetakan Kedua, Pt. Rineka Cipta, Jakarta.

[11] Johnson, M. Eric \& Whang, Seungjin. 2010. E-Business And Supply Chain Management : An Overview And Framework.

[12] Kuspriatni, Lista. 2011. Sistem Bisnis Elektronik.

[13] Leon-Pena, Jorge R. 2008. EBusiness And The Supply Chain Management.

[14]Mcdonough, Randy. 2012. Writing A Business Plan For A New Pharmacy Service.

[15] Miller, Michael. 2008. "Alpha Teach Yourself : Business Plan Dalam 24 Jam". Jakarta: Fajar Interpratama Offset.

[16]Mulyanto, Agus. 2009. "Konsep Sistem Informasi Dan Aplikasi". Surabaya: Pustaka Pelajar.
[17] Murpi, Solehudin. 2012. "Business Plan Praktik Dan Dahsyart Untuk Umkm". Jakarta: Laskar Aksara.

[18] Nemat, Rania. Volume 1, No 2. Juni 2011. Taking A Look At Different Types Of E-Commerce.

[19] Nugroho, Adi. 2010. "E-Commerce Memahami Perdangan Moderen Di Dunia Maya". Bandung: Informatika.

[20] Ostewalder, Alexander And Pigneur, Yves. 2012. "Business Model Generation". Jakarta: Elex Media Komputindo.

[21]Phan, Dien D. 2009. E-Business Development For Competitive Advantages : A Case Study.

[22] Putra T, Diah Et Al. 2011. "Entrepreneurial Skill Development Needs Of Potential Agri-Based Technopreneurs".

[23] Ramelan. 2012. "Business Model Canvas : Penerapan Di Indonesia". Jakarta: Ppm.

[24] Rangkuti, Fredy. 2009. "Creating Effective Marketing Plan". Jakarta: Gramedia Pustaka Utama.

[25] Rangkuti, Fredy. 2010. "Business Plan : Teknik Membuat Perencanaan Bisnis Dan Analisis Kasus". Jakarta: Gramedia Pustaka Utama.

[26] Riyanto, Bambang, 2012. "Dasar Dasar Pembelanjaan Perusahaan", Edisi Ketiga, Yayasan Badan Penerbit, Gadjah Mada, Yogyakarta

[27] Sensuse, Dana Indra \& Hendy Sopryadi. Volume 4 No 3 . Oktober 2008. Perencanaan Strategis Sistem Dan Teknologi Informasi Pada St. Ignatius Education Center Palembang.

[28] Shivani, Himani Grewal. 2012. ECommerce: Security Challenges \& Growth : An Indian Perspective.

[29] Sumardjani, Lisman. 2009. "Konsep Lima Kekuatan Porter Untuk Membedah Kondisi Industri Rotan Indonesia"

[30] Supriyanto. 2012. Business Plan Sebagai Langkah Awal Memulai Usaha. 